\section{The Use of Leaf Parts to Estimate the Cold Hardiness of Southern Magnolia (Magnolia grandiflora L.)}

\author{
Orville M. Lindstrom ${ }^{1}$ \\ Department of Horticulture, University of Georgia, Georgia Station, \\ Griffin, GA 30223 \\ Additional index words. sample size, ice nucleation, freeze tolerance, lowest survival \\ temperature
}

\begin{abstract}
Whole, half, and quarter leaves and leaf disks were used to make laboratory estimations of the cold hardiness of Magnolia grandiflora. The effects of ice nucleation temperatures, length of exposure to nucleating temperatures, rates of temperature drop, thawing regimes, and methods of injury analysis were investigated for each leaf type in the fall and midwinter. In general, whole and half leaves responded more consistently to freezing tests than did quarter leaves and leaf disks. The most critical factors in the freezing procedure are the temperature at which the samples are nucleated with ice crystals and the regime in which the samples are warmed. These data suggest that whole and half leaves can effectively be used to reliably predict the cold hardiness of southern magnolia leaves.
\end{abstract}

Southern magnolia is a commercially important landscape plant in hardiness zones 7 to 9 (Dirr, 1990). Low temperatures, however, limit its use in the northern United States, and severe winters may injure plantings throughout much of its range. The cold tolerance of well-established cultivars of $M$. grandiflora has been approximated through field observations, but little is known about newer selections. Lindstrom and Dirr (1990, 1991) used whole leaves to estimate the cold hardiness of several magnolia cultivars and found that laboratory estimations closely agreed with field observations. However, promising new magnolia selections often have little plant material available to conduct reliable freezing tests. For these cultivars it would be desirable to use smaller tissue parts to estimate cold hardiness. Several investigators have found, however, that small samples may not provide a reliable estimate of whole-plant cold hardiness (Ashworth and Davis, 1984; Ashworth et al., 1985a, 1985b). Therefore, the objective of this study was to identify a laboratory cold hardiness evaluation procedure for southern magnolia leaves that would be reliable for plants either partially or fully cold hardened. Specifically, this study examined the laboratory freezing procedure described by Dirr and Lindstrom (1990); Lindstrom and Dirr $(1990,1991)$ to compare cold hardiness estimates using half and quarter leaves and leaf disks of magnolia with those based on whole leaves.

Uniform leaves, selected from the 2nd year

Received for publication 12 Apr. 1991. Accepted for publication 17 Oct. 1991. I thank Glen Kent, Tonni McLain, Malgorzata Florkowska, and Evelyn Weatherly for their part in making this manuscript possible. The cost of publishing this paper was defrayed in part by the payment of page charges. Under postal regulations, this paper therefore must be hereby marked advertisement solely to indicate this fact.

'Assistant Professor. growth of established plantings (12 to 14 years old) from a single clone of southern magnolia located at the Georgia Station in Griffin, Ga., were used in all of the experiments in this study. Samples were collected from the field in October and February for the fall and winter experiments, respectively, and placed in plastic bags containing moist paper towels. Within $2 \mathrm{~h}$ of collection, the material was prepared for laboratory freezing tests as described by Dirr and Lindstrom (1990); Lindstrom and Dirr (1990, 1991) and with modifications noted below.

In this experiment, five variables of the freezing test as described by Lindstrom and Dirr (1990, 1991) were altered in the fall and midwinter with whole, half, quarter leaves, and leaf disks. The variables were: 1) ice nucleation temperature, 2) length of exposure to ice nucleating temperatures, 3 ) rate of temperature drop, 4) thawing regime, and 5 ) visual evaluation of injury. In separate experiments, each variable of the laboratory freezing procedure described above was varied as follows.

Ice nucleation temperature. Samples were sequently exposed to lower temperatures. placed in a freeze bath preset to -2 (control), -3 , or $-4 \pm 0.25 \mathrm{C}$ and were allowed to reach the bath temperature before nucleating with ice to promote freezing. After $12 \mathrm{~h}$ at each temperature, samples were cooled at $4 \mathrm{C} / \mathrm{h}$ and removed at successively lower temperature intervals through $-6 \mathrm{C}$ for the fall and at each $3 \mathrm{C}$ interval from -3 to $-30 \mathrm{C}$ for midwinter experiments. Each treatment was replicated 12 times in the fall and six times in midwinter.

Length of exposure at ice nucleating temperatures. Samples were placed in the freeze bath nucleated with ice, as described, and remained exposed to -2 or $-4 \pm 0.25 \mathrm{C}$, for 2 or $14 \mathrm{~h}$ (control). At the end of each 2- and 14-h treatment, samples were removed from the freeze bath and placed at 4C. Each treatment was replicated 16 times in the fall and six times in midwinter.

Rate of temperature drop. The temperature was lowered at either 2, 4 (control), or $6 \mathrm{C} / \mathrm{h}$. Samples were removed at $1 \mathrm{C}$ intervals from -2 to $-10 \mathrm{C}$ in the fall, and at $3 \mathrm{C}$ intervals from -3 to $-30 \mathrm{C}$ in midwinter. Each treatment was replicated 12 times in the fall, and six times in midwinter.

Thawing regime. Samples were removed at $1 \mathrm{C}$ intervals from -2 to $-7 \mathrm{C}$ in the fall and at $3 \mathrm{C}$ intervals from -3 to $-30 \mathrm{C}$ in midwinter. They were placed to thaw at either room temperature $(23 \pm 3 \mathrm{C})$ or on ice for $2 \mathrm{~h}$ and then room temperature, or at $4 \pm$ $1.0 \mathrm{C} / 24 \mathrm{~h}$ (control). Each treatment was replicated 12 times in the fall and six times in midwinter.

Evaluation of injury. Two groups of samples of whole leaves were placed in the freeze bath and nucleated with ice. A set of samples was removed at $3 \mathrm{C}$ intervals from -3 to $-30 \mathrm{C}$ and placed at $4 \mathrm{C}$. The control group of whole leaves was evaluated for injury visually (Fuchigami et al., 1971; Hummel et al., 1982; Smithberg and Weiser, 1968; Stergios and Howell, 1973; van Huystee et al., 1967). The second group of whole leaves was prepared for cell electrolyte leakage evaluation (Dexter et al., 1932; Palta and Li, 1978). Six disks from each whole leaf were placed in $25 \mathrm{ml}$ of deionized water. Each treatment was replicated eight times and was conducted only in midwinter.

Table 1. Percent of southern magnolia leaves killed when nucleated at $-2,-3$, or $-4 \mathrm{C}$ and sub-

\begin{tabular}{|c|c|c|c|c|c|c|c|c|c|}
\hline \multirow{4}{*}{$\begin{array}{c}\text { Leaf } \\
\text { portion }\end{array}$} & \multicolumn{9}{|c|}{ Nucleation temp $\left({ }^{\circ} \mathrm{C}\right)$} \\
\hline & \multicolumn{3}{|c|}{-2} & \multicolumn{3}{|c|}{-3} & \multicolumn{3}{|c|}{-4} \\
\hline & \multicolumn{9}{|c|}{ Exposure temp $\left({ }^{\circ} \mathrm{C}\right)$} \\
\hline & -4 & -5 & -6 & -4 & -5 & -6 & -4 & -5 & -6 \\
\hline & & & & & Fall & & & & \\
\hline Whole & 0 & 0 & 100 & 0 & 75 & 88 & 0 & 67 & 100 \\
\hline Half & 0 & 0 & 100 & 0 & 75 & 88 & 0 & 67 & 75 \\
\hline Quarter & 0 & 0 & 92 & 0 & 50 & 88 & 0 & 58 & 100 \\
\hline \multirow[t]{3}{*}{ Disk } & 0 & 0 & 67 & 0 & 0 & 0 & 0 & 100 & 100 \\
\hline & $-18 \mathrm{C}$ & $-21 \mathrm{C}$ & $-24 \mathrm{C}$ & $-18 \mathrm{C}$ & $-21 \mathrm{C}$ & $-24 \mathrm{C}$ & $-18 \mathrm{C}$ & $-21 \mathrm{C}$ & $-24 \mathrm{C}$ \\
\hline & \multicolumn{9}{|c|}{ Midwinter } \\
\hline Whole & 33 & 33 & 100 & 33 & 50 & 83 & 17 & 67 & 100 \\
\hline Half & 33 & 33 & 100 & 33 & 50 & 100 & 17 & 67 & 100 \\
\hline Quarter & 50 & 50 & 100 & 83 & 83 & 83 & 0 & 100 & 100 \\
\hline Disk & 33 & 100 & 100 & 100 & 100 & 100 & 0 & 50 & 100 \\
\hline
\end{tabular}


Table 2. Percent of southern magnolia leaves killed using three different thawing regimes.

\begin{tabular}{|c|c|c|c|c|c|c|}
\hline \multirow[b]{3}{*}{$\begin{array}{c}\text { Leaf } \\
\text { portion }\end{array}$} & \multicolumn{6}{|c|}{ Thawing regime } \\
\hline & \multicolumn{3}{|c|}{$\begin{array}{c}\text { From }-6 \mathrm{C} \\
\text { (fall) }\end{array}$} & \multicolumn{3}{|c|}{$\begin{array}{l}\text { From }-21 \mathrm{C} \\
\text { (midwinter) }\end{array}$} \\
\hline & $\begin{array}{c}\text { On ice } \\
2 \mathrm{~h} \\
\end{array}$ & $\begin{array}{r}4 \mathrm{C} \\
24 \mathrm{~h} \\
\end{array}$ & $\begin{array}{c}\text { Room } \\
\text { temp }\end{array}$ & $\begin{array}{c}\text { On ice } \\
2 \mathrm{~h}\end{array}$ & $\begin{array}{c}4 \mathrm{C} \\
24 \mathrm{~h}\end{array}$ & $\begin{array}{c}\text { Room } \\
\text { temp }\end{array}$ \\
\hline Whole & 0 & 25 & 38 & 33 & 33 & 67 \\
\hline Half & 38 & 38 & 63 & 33 & 33 & 67 \\
\hline Quarter & 50 & 88 & 50 & 50 & 100 & 83 \\
\hline Disks & 50 & 50 & 50 & 67 & 100 & 67 \\
\hline
\end{tabular}

Cold hardiness is reported as the lowest survival temperature (LST) (Sakai, 1986) or as percent killed (Levitt, 1980). Four types of leaf samples were used in each experiment; whole, half, and quarter leaves and leaf disks $(12 \mathrm{~mm})$. Half leaves were prepared by cutting perpendicular to the midrib at a point equidistant from the leaf tip and the leaf base-petiole interface. Quarter leaves were formed in a similar fashion by cutting the top and bottom leaf halves in two equal parts. Four leaf disks were taken from whole leaves, two from the upper half and two from the lower half of the leaf. One disk containing the midrib and one disk without a midrib were taken from each of the upper and lower leaf halves. In every experiment, each replication consisted of one whole leaf, two half leaves, four quarter leaves, and four leaf disks.

Leaf samples in test tubes were placed in a freeze bath, and the temperature of the freeze bath was lowered. Whole, half, and quarter leaves and leaf disks were removed at successive $1 \mathrm{C}$ intervals from -2 to $-10 \mathrm{C}$ for the fall samples, and $3 \mathrm{C}$ intervals from -3 to $-30 \mathrm{C}$ for the winter samples. Each treatment was replicated 12 times in both the fall and midwinter experiments.

No differences were found in injury, regardless of the position from which the half leaves, quarter leaf sections, or leaf disks were removed from the whole leaf. Therefore, all replications of these leaf types were pooled to estimate their cold hardiness. When using all control variables of the freezing procedure of Lindstrom and Dirr (1990, 1991), cold hardiness was $-5 \mathrm{C}$ in the fall for whole, half, and quarter leaves or leaf disks. However, greater variability was noted within the quarter leaf and leaf disk samples than within the whole and half leaves. In midwinter, whole and half leaves were cold hardy to $-21 \mathrm{C}$, whereas the cold hardiness of quarter leaves and leaf disks was -18 and $-12 \mathrm{C}$, respectively, and exhibited high variability.

Length of exposure at ice nucleation temperatures. No injury was observed in the leaf tissue for any exposure time up to $14 \mathrm{~h}$ for samples kept at either -2 or -4 C. All sampled sizes responded similarly in the fall and midwinter.

Ice nucleation temperature. Differences in the percentage of samples killed were found when the temperature of nucleation with ice was varied in the fall and midwinter experiments (Table 1). Fall samples, nucleated at $-2 \mathrm{C}$, were not injured when exposed to -4 and $-5 \mathrm{C}$ but were killed when exposed to $-6 \mathrm{C}$. However, when samples were nu- cleated at -3 or $-4 \mathrm{C}$ and exposed to -5 and $-6 \mathrm{C}$, at least $50 \%$ of the whole, half, and quarter leaves were killed. Leaf disks responded similarly, except when nucleated at $-3 C$, where none of the leaf disks were killed. Similar results were found in the midwinter experiments for whole and half leaves. Fewer than $50 \%$ of whole and half leaf samples that were nucleated at $-2 \mathrm{C}$ were killed at $-21 \mathrm{C}$, but, when nucleated at -3 or $-4 \mathrm{C}$ and exposed to -21 and $-24 \mathrm{C},>50 \%$ of the samples were killed. Both the quarter leaves and the leaf disks showed variable results with no obvious trends.

Rate of temperature drop. There were few differences in survival of whole, half, and quarter leaves or leaf disks when cooled at 2,4 , or $6 \mathrm{C} / \mathrm{h}$ in the fall or midwinter experiments. A slight decrease in the LST estimate was noted at the $2 \mathrm{C} / \mathrm{h}$ cooling rate with whole leaves. In midwinter, more variability was noted in the quarter-leaf and leaf disk samples than in the whole- and half-leaf samples.

Thawing regime. Data collected from samples of all leaf types showed differences in survival when thawed differently. In the fall, all leaf types survived, regardless of thawing regime, when exposed to $-2,-3$, -4 , or $-5 \mathrm{C}$, but demonstrated a differential response when warmed from $-6 \mathrm{C}$ by various regimes (Table 2). Thawing wholeand half-leaf samples on ice for $2 \mathrm{~h}$ or at $4 \mathrm{C}$ killed $\leq 38 \%$ of the leaves or leaf parts, whereas when thawed directly at room temperature, $38 \%$ of the whole-leaf and $63 \%$ of the half-leaf samples were killed. Regardless of thawing regime, $\geq 50 \%$ of the quarter-leaf samples and leaf disks were killed when warmed from -6C. All samples, regardless of thawing regime, were killed when exposed to $-7 \mathrm{C}$. In the midwinter experiments, similar results were found. Two-thirds of whole- and half-leaf samples were killed when thawed at room temperature, but only one-third were killed when thawed at $4 \mathrm{C}$ or on ice. Again, quarter leaves and leaf disks had $\geq 50 \%$ of their samples killed regardless of thawing regime. All samples, regardless of thawing regime, were killed when exposed to temperatures lower than -21C.

Evaluation of injury. Visual evaluation proved to be more sensitive to tissue injury of whole leaves than did electrolyte leakage. There was no injury observed in the leaves when exposed to temperatures down to $-15 \mathrm{C}$, but $50 \%$ of the leaves were dead at $-18 \mathrm{C}$. Electrolyte leakage measurements were similar for the control and for samples exposed to as low as -18C; however, sam- ples exposed to -21 and $-24 \mathrm{C}$ had $>50 \%$ leakage. The LST from these data, based on Sakai (1986) and Levitt (1980), is -15 and $-18 \mathrm{C}$ for the visual and electrolyte leakage evaluation techniques, respectively.

Laboratory cold hardiness determinations using whole magnolia leaves as described by Lindstrom and Dirr $(1990,1991)$ closely agree with field observations. The present data, however, indicate that the use of smaller leaf parts, especially quarter leaves and leaf disks, is not as consistent in predicting cold tolerance as are whole magnolia leaves, although in some cases, the quarter leaves and leaf disks gave similar cold hardiness estimates as whole and half leaves. However, in other cases, the variability increased and the cold hardiness estimates measurement differed from those derived from half and whole leaves

Such differences have been observed in other systems. Ashworth et al. (1985a) found that small portions of plants do not always reflect the cold hardiness of the whole plant. It is plausible that the smaller tissue pieces are not frozen when nucleated with ice, even though they are wrapped in moist cheesecloth. If the samples undercool to lower temperatures before freezing, they can be killed at that point and not manifest their full cold hardiness potential (Lindstrom and Carter, 1983). If the samples remain undercooled throughout the experiment, they may be undamaged. This could account for the variability in the response of the quarter leaves and leaf disks.

These data also affirm that the variables used in the laboratory freezing procedure described by Lindstrom and Dirr (1990, 1991) are appropriate for estimating the cold hardiness of southern magnolia. There was no effect on the leaf samples when left up to 14 $h$ at the nucleating temperature of -2 or $-4 \mathrm{C}$. In the procedure described by LindStrom and Dirr $(1990,1991)$ the samples were left at $-2 \mathrm{C}$ for 12 to $14 \mathrm{~h}$ after nucleating with ice. Magnolia leaves that were nucleated with ice at -3 and $-4 \mathrm{C}$ exhibited injury at a higher temperature than those leaves that were initiated at $-2 \mathrm{C}$, the control temperature. This phenomenon has been previously reported (Lindstrom, 1981; Lindstrom and Carter, 1983; Rajashekar et al., 1983). The cooling rate did not affect the results of the laboratory procedure at rates of 2 to $6 \mathrm{C} / \mathrm{h}$. The thawing regime did, however, influence the estimates of cold hardiness levels of whole and half magnolia leaves. Removing the samples directly to room temperature resulted in the greatest injury. Placing sampels at $4 \mathrm{C}$ for $24 \mathrm{~h}$ or on ice for $2 \mathrm{~h}$ before exposing them to room temperature produced less injury to the whole and half leaves than removing the samples and exposing them directly to room temperature. The visual analysis procedure detected freeze injury at a higher temperature than did the electrolyte leakage procedure. In these freezing tests there was a sharp visual difference between injured leaves and noninjured leaves. Therefore, the estimates derived from the visual observation of different observers, or 
the same observer at different times, were uniform and repeatable.

Caution must be taken to appropriately sample magnolias for reliable determination of cold hardiness. Whole and half leaves produce similar results, but quarter leaves and leaf disks do not respond uniformly under all conditions. The most critical factors in the freezing procedure are the temperature at which the samples are nucleated with ice crystals and the method in which the samples are warmed. If a procedure such as outlined by Lindstrom and Dirr $(1990,1991)$ is used, whole or half leaves can credibly estimate the cold hardiness of southern magnolia.

\section{Literature Cited}

Ashworth, E.N. and G.A. Davis. 1984. Ice nucleation within peach trees. J. Amer. Soc. Hort. Sci. 109:198-201.

Ashworth, E.N., G.A. Davis, and J.A. Anderson. 1985a. Factors affecting ice nucleation in plant tissues. Plant Physiol. 79:1033-1037.

Ashworth, E.N., J.A. Anderson, and G.A. Davis. 1985b. Properties of ice nuclei associated with peach trees. J. Amer. Soc. Hort. Sci. 110:287291.

Dexter, S.T., W.E. Tottingtham, and L.F. Garber. 1932. Investigation of the hardiness of plants by measurement of electrical conductivity. Plant Physiol. 7:63-78.

Dirr, M.A. 1990. Manual of woody landscape plants. 4th ed. Stipes, Champaign, Ill.

Dirr, M.A. and O.M. Lindstrom Jr. 1990. Leaf and stem cold hardiness of 17 broadleaf evergreen taxa. J. Environ. Hort. 8:71-73.

Fuchigami, L.H., C.J. Weiser, and D.R. Evert. 1971. Induction of cold acclimation in Cornus stolonijera Michx. Plant Physiol. 47:98-103.

Hummel, R.L., P.D. Ascher, and H.M. Pellett. 1982. Inheritance of the photoperiodically induced cold acclimation response in Cornus sericea L., Red-osier dogwood. Theoretical Applied Genet. 62:385-394.

Levitt, J. 1980. Response of plants to environmental stresses, 2nd ed. vol. I: Temperature stress. Academic, New York, p. 116-152.

Lindstrom, O.M. 1981. The effects of subzero temperatures on winter rye and potato plants. $\mathrm{PhD}$ Diss.. Univ. of Minnesota. Minneapolis.

Lindstrom, O.M. and J.V. Carter: 1983. Assessment of freezing injury of cold-hardened undercooled leaves of Solanum commersonii. CryoLetters 4:361-370.

Lindstrom, O.M. and M.A. Dirr. 1990. Cold hardiness of Magnolia grandiflora cultivars. Southern Nurserymen's Res. Conf. 35:282-284.

Lindstrom, O.M. and M.A. Dirr. 1991. Cold hardiness of Magnolia grandiflora cultivars. J. Environ. Hort. 9:116-118.

Palta, J.P. and P.H. Li. 1978. Cell membrane properties in relation to freezing injury, p. 93115. In: P.H. Li and A. Sakai (eds.). Plant cold hardiness and freezing stress. Academic, New York.

Rajashekar, C.B., P.H. Li, and J.V. Carter. 1983. Frost injury and heterogeneous ice nucleation in leaves of tuber-bearing Solanum species. Plant Physiol. 71:749-755.

Sakai, A., L. Fuchigami, and C.J. Weiser, 1986. Cold hardiness in the genus Rhododendron. J. Amer. Soc. Hort. Sci. 111:273-280.

Smithberg, M.H. and C.J. Weiser. 1968. Patterns of variation among climatic races of redosier dogwood. Ecology 49:495-505.

Stergios, B.G. and G.S. Howell, Jr. 1973. Eval- uation of viability tests for cold stressed plants. J. Amer. Soc. Hort. Sci. 98:325-330. van Huystee, R.B., C.J. Weiser, and P.H. Li.
1967. Cold acclimation in Cornus stolonifera under natural and controlled photoperiod and temperature. Bot. Gaz. 128:200-205. 